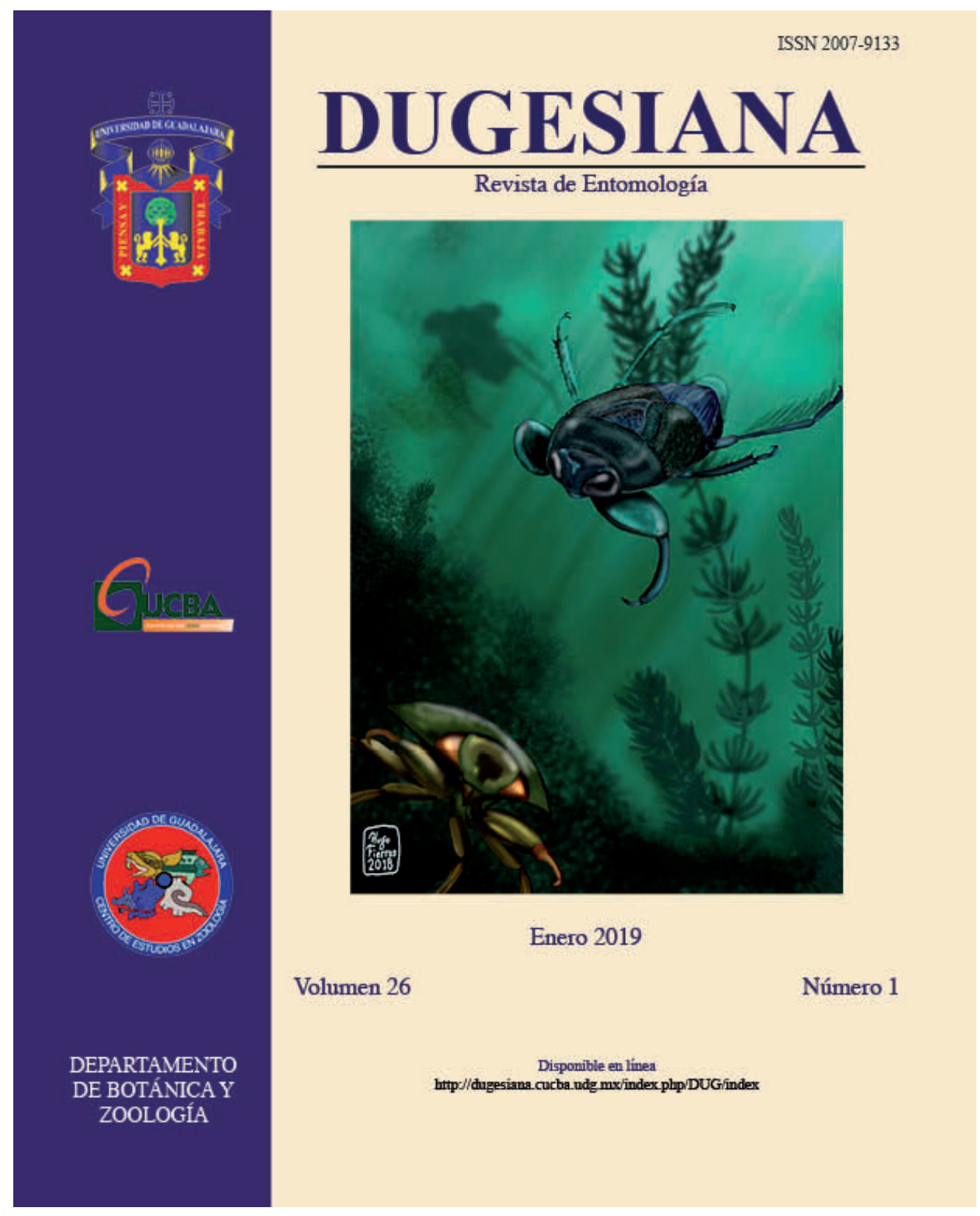

DUGESIANA, Año 26, No.1, 2019 (primer semestre de 2019) es una publicación Semestral editada por la Universidad de Guadalajara, a través del Centro de Estudios en Zoología, por la División de Ciencias Biológicas y Ambientales, CUCBA. Km. 15.5 carr. a Nogales, Predio Las Agujas s/n, Nextipac, C.P. 45100. Zapopan, Jalisco, México. Tel. 37771150, http://dugesiana.cucba.udg.mx/index.php/DUG/index, glenusmx@gmail.com, Editor responsable: José Luis Navarrete Heredia. Reserva de Derechos al Uso Exclusivo 04-2009-062310115100-203, ISSN: 2007-9133, otorgados por el Instituto Nacional del Derecho de Autor. Responsable de la última actualización de este número: José Luis Navarrete Heredia, Editor y Ana Laura González-Hernández, Asistente Editorial. Fecha de la última modificación 1 de enero de 2019, con un tiraje de un ejemplar.

Las opiniones expresadas por los autores no necesariamente reflejan la postura del editor de la publicación.

Queda estrictamente prohibida la reproducción total o parcial de los contenidos e imágenes de la publicación sin previa autorización de la Universidad de Guadalajara. 


\title{
Taxonomic overview of the family Naucoridae (Heteroptera: Nepomorpha) in Mexico
}

\author{
Sinopsis de la familia Naucoridae (Heteroptera: Nepomorpha) en México
}

\author{
Daniel Reynoso-Velasco ${ }^{1 *}$ and Robert W. Sites $^{2}$ \\ ${ }^{1}$ Red de Biodiversidad y Sistemática, Instituto de Ecología A.C. (INECOL), Carretera Antigua a Coatepec 351, \\ El Haya, Xalapa, Veracruz 91070, MÉXICO. E-mail: daniel.reynoso@inecol.mx; ${ }^{2} E n n s$ Entomology Museum, \\ Division of Plant Sciences, University of Missouri, Columbia, Missouri 65211, U.S.A. E-mail: sitesr@missouri. \\ edu. *Corresponding author.
}

\begin{abstract}
The state of taxonomy of the Mexican fauna of the family Naucoridae is summarized and is fairly complete as a result of recent research. Currently, 71 species from six genera and four subfamilies have been recorded from the country. Species richness is distributed in the subfamilies Cryphocricinae: Ambrysus Stål (53), Cataractocoris Usinger (3), Cryphocricos Signoret (2); Laccocorinae: Interocoris La Rivers (1); Limnocorinae: Limnocoris Stål (10); and Naucorinae: Pelocoris Stål (2). Recent works have focused on the fauna of the genus Ambrysus. Additionally, studies are required for the genera Cryphocricos and Pelocoris, while a taxonomic revision of the genus Limnocoris is close to completion. A key to the subfamilies and genera of Naucoridae from Mexico is provided.
\end{abstract}

Key words: distribution, aquatic insects, Hemiptera, North America.

Se resume el conocimiento taxonómico de la fauna Mexicana de la familia Naucoridae, el cual es bastante completo debido a estudios recientes. Actualmente se encuentran registradas para el país 71 species pertenecientes a seis géneros y cuatro subfamilias. La riqueza de especies está distribuida en las subfamilias Cryphocricinae: Ambrysus Stål (53), Cataractocoris Usinger (3), Cryphocricos Signoret (2); Laccocorinae: Interocoris La Rivers (1); Limnocorinae: Limnocoris Stål (10); and Naucorinae: Pelocoris Stål (2). Trabajos recientes han enfocado su atención en el estudio del género Ambrysus. Adicionalmente se requieren estudios de los géneros Cryphocricos y Pelocoris, mientras que la revision taxonómica del género Limnocoris está cerca de ser finalizada. Se proporciona una clave para la identificación de las subfamilias y géneros de Naucoridae de México.

Palabras clave: distribución, insectos acuáticos, Hemiptera, Norteamérica.

Naucoridae Leach is a family of ovate and dorsoventrally flattened aquatic insects in the order Hemiptera (Fig. 1). It is one of the 11 families in the heteropteran infraorder Nepomorpha (Schuh and Slater 1995), which includes approximately 2,400 described species worldwide (Polhemus and Polhemus 2008a). The insects in the family Naucoridae are commonly known as saucer bugs or creeping water bugs. Naucorids are common predators in tropical lentic and lotic habitats worldwide with less representation in temperate regions. These insects grasp their prey with retentorial forelegs while using the piercingsucking mouthparts to feed upon the predigested prey contents. The type of habitat preferred by saucer bugs is diverse, but they are commonly found associated with marginal submerged vegetation in lentic and lotic situations and among rocks in shallow areas close to the margins of streams. A remarkable environment is that inhabited by species in the genus Cataractocoris Usinger, which prefer the near-vertical rock faces of waterfalls (Fig. 2), waterfall splash zones, and large rocks in fast current. Several Asian genera in the subfamily Laccocorinae also occupy the rock faces of waterfalls.

The currently accepted classification of Naucoridae includes the subfamilies Cheirochelinae, Cryphocricinae, Laccocorinae, Limnocorinae, and Naucorinae (Štys and Jansson 1988). The subfamily Cheirochelinae, which has no representatives in Mexico, is distributed in India, southern China, Southeast Asia, Borneo, and New Guinea; Cryphocricinae is found only in the New World with the highest diversity in North America; Laccocorinae is mainly distributed in the Old World with few representatives in the New World; Limnocorinae is distributed only in the New World with the highest diversity in South America; and Naucorinae is cosmopolitan. The family Naucoridae includes 40 genera and approximately 400 described species, approximately half of which occur in the New World.

For most of the Mexican insect fauna our taxonomic knowledge is inadequate. Thus, accurate information regarding species richness, diversity, biology, distribution, phylogenetic relationships, ecological roles, and economic importance is not available. In particular, this applies to most Mexican aquatic and semi-aquatic Heteroptera, except for Naucoridae, which has been studied in recent years. The aquatic and semi-aquatic Heteroptera (Gerromorpha, Leptopodomorpha, Nepomorpha) represent an important component of the world's aquatic insect biota with 23 families, 343 genera, and 4,810 species (Polhemus and Polhemus 2008a). However, in Mexico relatively few works (e.g., Usinger 1946, La Rivers 1953) from sporadic and scattered collecting trips have provided a limited understanding of the taxonomy, species richness, and distribution of these aquatic and semi-aquatic groups.

\section{Taxonomic History}

The first major taxonomic contributions to understanding the Mexican saucer bug fauna were by the French entomologist Arnold L. Montandon, who at the end 

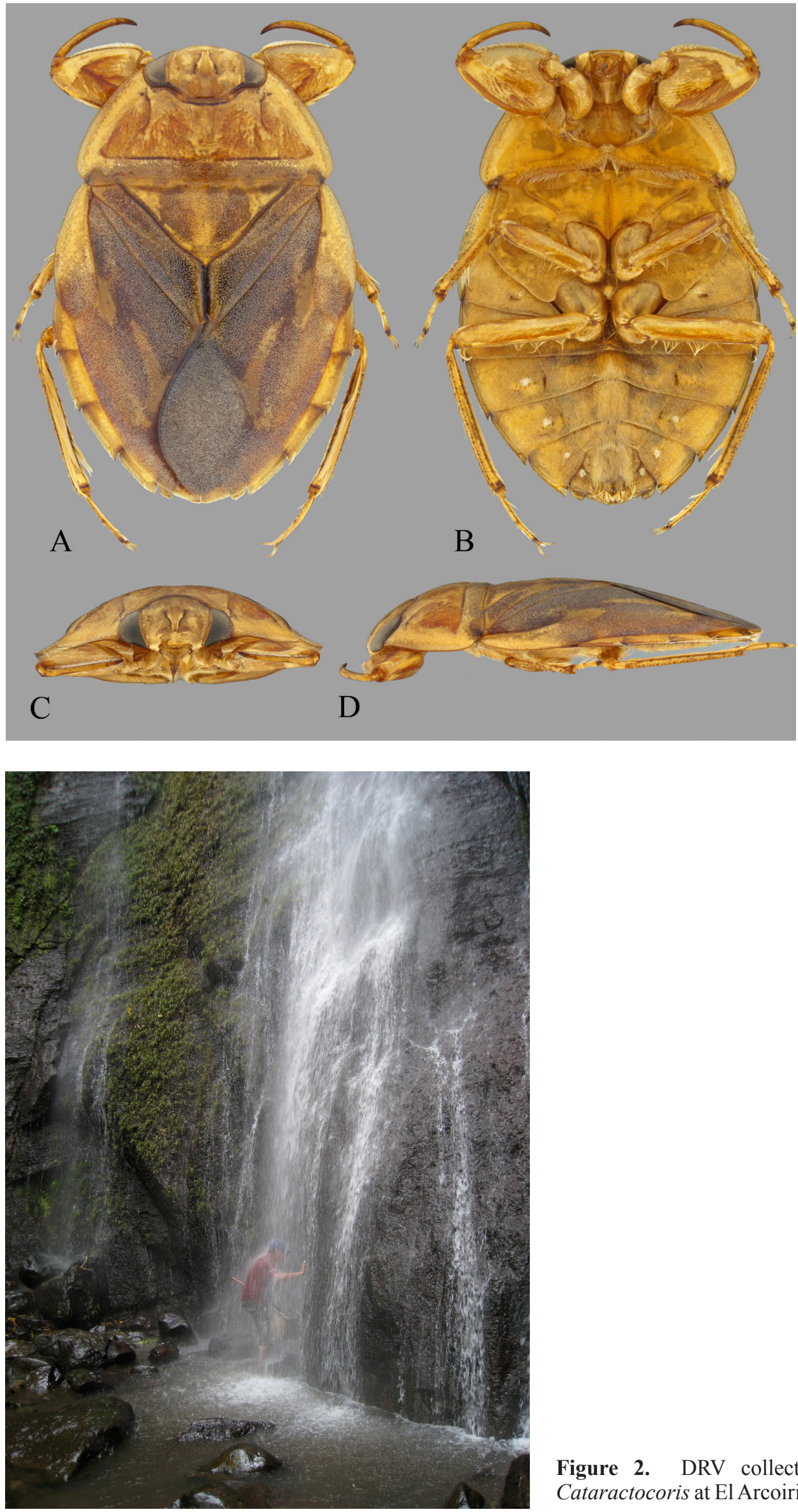

Figure 1. Female of Ambrysus signoreti. (A) dorsal habitus, (B) ventral habitus, (C) frontal view of head, prothoracic legs, and prothorax (D) lateral view of left side.
Figure 2. DRV collecting specimens of the genus Cataractocoris at El Arcoiris waterfall in Veracruz, Mexico. 
of the 19th century described 10 of the species currently known to be distributed in Mexico, including Ambrysus mexicanus Montandon. Later into the 20th century, American entomologists Ira La Rivers and Robert L. Usinger provided description of many new taxa.

In 1946, Usinger published a study in which he described 16 new species in the genus Ambrysus Stål; 10 species were from Mexico, five of them collected personally during his two-month collecting trip to central Mexico in 1933. During the trip to the Estado de México, collecting took place around the towns of Tejupilco and Temascaltepec. Usinger (1972) later explained that he collected thousands of specimens and considered the area as "The original home of the Naucoridae." He described collecting in the area as "fantastic," because he was able to collect more subfamilies, genera, and species of Naucoridae than those reported by Champion (1901) for Central America in the Biologia Centrali-Americana (Usinger 1972).

Although La Rivers published several small works dealing with the Mexican Naucoridae, his most important contribution was the revision of the genus Ambrysus of Mexico (La Rivers 1953), which was a complement to his revision of the genus in the United States (La Rivers 1951). An important contribution from these works was the use of structures associated with the terminal abdominal segments of males and females as diagnostic features. Formerly, the species descriptions were based on gross morphological characteristics such as body length, width, color, and features of the pronotum and hemelytra surface. La Rivers was the first to use the shape of the posterior margin of the female seventh mediosternite (subgenital plate) and the shape of the male accessory genitalic process of the sixth tergum for species determination. These two features are still commonly used to determine and diagnose species (e.g., Sites and Shepard 2015, Sites and Reynoso-Velasco 2015).

La Rivers (e.g., 1951) designated distinct species complexes within the genus Ambrysus, but in many cases he did not provide sufficient unifying attributes or define the complexes based on the same features. For example, La Rivers (1957) compared the $A$. mexicanus and $A$. signoreti species complexes using contrasting character states of body shape, embolium width, coloration, and production of posterolateral corners of the abdominal segments. However, the $A$. hybridus species complex was defined based on other features, including the overall similar shape of the male accessory genital process and the female subgenital shape (La Rivers 1957). Furthermore, the presence of strikingly different morphological features led to the establishment of different monotypic species complexes.

Until the end of the 20th Century, the Mexican fauna of Naucoridae was represented by 55 described species in six genera and four subfamilies. Cryphocricinae was the most species-rich subfamily with 42 species in three genera, followed by Limnocorinae with 10 species in its single genus, Naucorinae with 2 species in one genus, and Laccocorinae with a single representative (Hungerford 1936; La Rivers 1971, 1976; Polhemus and Polhemus 1981, 1983; Davis 1986, 1996; Polhemus and Sites 1995).

\section{Recent Taxonomic Research}

In 2012, we undertook a project to clarify the taxonomy of the family Naucoridae in Mexico. An important aspect of this study was to evaluate the reliability of the diagnostic features used by La Rivers for species identification. Frequently, we were unable to identify specimens using his characters; thus, we were concerned that unrecognized intraspecific variation resulted in species being described more than once. To investigate intraspecific variation, we endeavored to examine as many specimens as possible within and among populations throughout the range of each species.

The first obstacle we encountered was the small number of specimens of Naucoridae deposited in different collections. La Rivers (1951) faced the same problem when trying to revise the entire genus Ambrysus. Thus, we examined material from as many collections as possible (including type material) and conducted extensive collecting throughout the country to maximize the opportunity to detect intraspecific variation.

The museum collections where we examined material or from which we obtained material on loan were: American Museum of Natural History (New York, United States), Bohart Museum of Entomology (Davis, United States), Brigham Young University (Provo, United States), California Academy of Sciences (San Francisco, United States), California State Collection of Arthropods (Sacramento, United States), Carnegie Museum of Natural History (Pittsburgh, United States), Colección Entomológica de la Universidad Autónoma de Querétaro (Juriquilla, Mexico), Colección Entomológica del Instituto de Ecología A.C. (Xalapa, Mexico), Colección Nacional de Insectos, Universidad Nacional Autónoma de México (Mexico City, Mexico), Escuela Agrícola Panamericana, Universidad Zamorano (San Antonio de Oriente, Honduras), Essig Museum of Entomology Collection (Berkeley, United States), Field Museum of Natural History (Chicago, United States), Illinois Natural History Survey (Champaign, United States), Muséum National d'Histoire Naturelle (Paris, France), Natural History Museum of Los Angeles County (Los Angeles, United States), Naturhistorisches Museum (Vienna, Austria), New Mexico State University (Las Cruces, United States), Snow Entomological Museum Collection, University of Kansas (Lawrence, United States), Swedish Museum of Natural History (Stockholm, Sweden), Texas A\&M University (College Station, United States), Texas Natural History Collections, Entomology Collection (Austin, United States), The Natural History Museum (London, England), United States National Museum of Natural History (Washington D.C., United States), Universidad del Valle de Guatemala (Guatemala City, Guatemala), University of Idaho Entomological Collection (Moscow, United States), University of Michigan Museum of Zoology (Ann Arbor, United States), University of Missouri (Columbia, United States), Washington State University Collection (Pullman, United States), Zoologisches Museum Hamburg (Hamburg, Germany), Zoologische Staatssammlung (Munich, Germany).

We complemented the information obtained from specimens deposited in the museum collections with the more than 10,000 specimens we collected from 432 localities throughout the country (Fig. 3). To maximize representation of the fauna in Mexico, we collected in all 


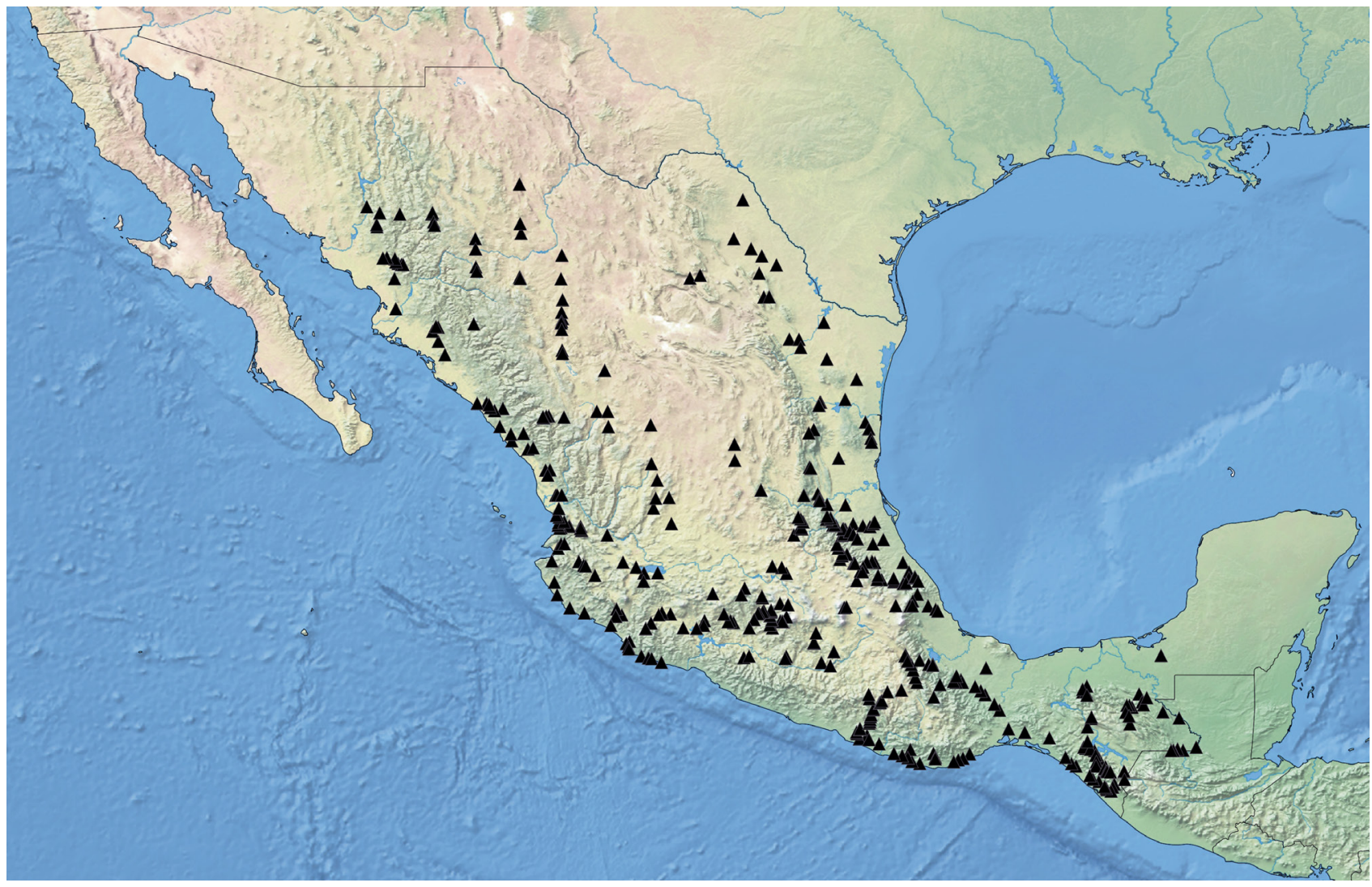

Figure 3. The 432 localities where we collected samples for the project on the Mexican fauna of Naucoridae.

but three of Mexico's biogeographic provinces (Morrone 2005). We did not collected in the two provinces in the Baja California Peninsula because of the low overall species richness of the area and because that fauna was well represented in collections from the western United States. We also did not collect in Yucatan Peninsula province due to the small number of surficial waters. Photographs of the collection sites identified as L-numbers are available in a Locality Image Database via a link from the internet site of the Enns Entomology Museum, University of Missouri.

During the still ongoing project, we have found that La Rivers' diagnostic features (shape of the male accessory genitalic process and female subgenital plate) are informative for species identification. In most cases, the subgenital plate provides the most reliable diagnostic information. We have also found that La Rivers' diagnostic characteristics exhibit substantial intraspecific variation, which can occur within and/or among populations. This is important because several species and subspecies were described based on only a few specimens from distant populations and the variation of the diagnostic features was not assessed.

A clear example of a species exhibiting intraspecific variation is A. circumcinctus Montandon. Using primarily the shape of the posterior margin of the female subgenital plate, La Rivers (1967) considered this species to be represented by three subspecies: Ambrysus c. extremus La Rivers from Costa Rica and Honduras, A. c. concavus La Rivers from Mexico (Nuevo León and San Luis Potosí), and the nominate $A$. c. circumcinctus from the southern United States (New Mexico and Texas). A fourth subspecies, $A$. c. caliginosus Usinger, was designated by La Rivers but was distinguished from the nominate subspecies based only on size and general coloration. Reynoso-Velasco et al. (2016) found that what La Rivers considered to be a stable and consistent feature instead was an artifact of the small number of specimens and localities used to describe the subspecies. At various localities in the range of $A$. circumcinctus, populations exhibit the characteristics of more than one described subspecies (Reynoso-Velasco et al. 2016), which is contrary to the concept of the subspecies as a geographical variety (Mayr 1982) with morphological uniformity in one or a few diagnostic characters (Wilson and Brown 1953). Reynoso-Velasco et al. (2016) proposed the four subspecies to be synonymized and recognized the presence of a single species, A. circumcinctus, with the expected variation in the shape of the subgenital plate throughout its wide range.

Because the Ambrysus species complexes were proposed by La Rivers using eclectic rather than homologous features, there is concern that they might not be consistent with phylogeny. At an early stage of our study, we found that the medial lobes of the male eighth tergum (pseudoparameres) and characteristics of the phallosoma could be important diagnostic features at the species and species complex levels. More specifically, features of the phallosoma have been used to better define and circumscribe the species complexes in Ambrysus (e.g., Reynoso-Velasco and Sites 2016a, b). The pseudoparameres can sometimes be informative at the species level, as in the case of species in the subgenus Syncollus present in Mexico (ReynosoVelasco et al. 2016), or at the species complex level, as in 
the case of the A. guttatipennis Stål complex (ReynosoVelasco and Sites 2016a).

As a result of this ongoing project, we have presented seven papers in which we treated the taxonomy of elements of the Mexican fauna of Naucoridae. We have primarily focused our efforts in studying Cryphocricinae because this subfamily possesses the highest species richness in Naucoridae. Initially, we revised the genus Cataractocoris (Sites et al. 2013), then focused our attention on the genus Ambrysus (Sites and Reynoso-Velasco 2015; ReynosoVelasco and Sites 2016a, 2016b, 2018a, 2018b; ReynosoVelasco et al. 2016), which is the most species-rich genus in this family and comprises more species that do any of the subfamilies of Naucoridae. In addition, the highest species richness of this genus is centered in Mexico.

Based partially on our recent studies, the current list of species present in Mexico includes 71 described species in six genera and four subfamilies. Because we have focused our research on Cryphocricinae, all recent taxonomic changes have taken place in this subfamily, which in Mexico is represented by 58 species in three genera.

\section{Current State of Taxonomy}

At the present time, the taxonomy of the Mexican fauna of Naucoridae is fairly well understood and nearly complete. Regarding the subfamily Cryphocricinae, the revision of the North American fauna of the most species-rich genus Ambrysus is in progress and close to completion. The genus Cataractocoris (Fig. 4) has been revised (Sites et al. 2013) and all three recognized species are present in Mexico. However, the genus Cryphocricos Signoret (Fig. 5) is in need of a comprehensive taxonomic revision. This genus is more diverse in South America, and in Mexico it has only two representatives. The distinction between the two Mexican species is based on body length, hemelytra mensural features, and characteristics of the posterolateral corners of abdominal segments (Usinger 1947). Cryphocricos hungerfordi Usinger is widespread and common in Mexico, whereas C. mexicanus Usinger has not been recorded since the type series was collected in 1933. A detailed study using more stable and informative morphological features and molecular data could help to clarify the taxonomy of the genus. The Mexican fauna of this subfamily represents $83 \%$ of the total species of Naucoridae known in the country.

The subfamily Limnocorinae currently comprises 73 described species in a single genus and is represented in Mexico by 10 species. Higor D. D. Rodrigues recently completed a taxonomic revision of the genus Limnocoris Stål (Fig. 6) as his dissertation research and is preparing it for publication. Several synonymies will be proposed for species reported from Mexico, as well as new records, and the description of at least one new species (H.D.D. Rodrigues, pers. comm.).

The subfamily Laccocorinae is the third most speciesrich subfamily and in Mexico it is represented only by the monotypic genus Interocoris La Rivers. Interocoris mexicanus (Usinger) (Fig. 7) was originally described in the genus Heleocoris Stål (Usinger 1935) and was placed in the subgenus Interocoris by La Rivers (1974) to distinguish

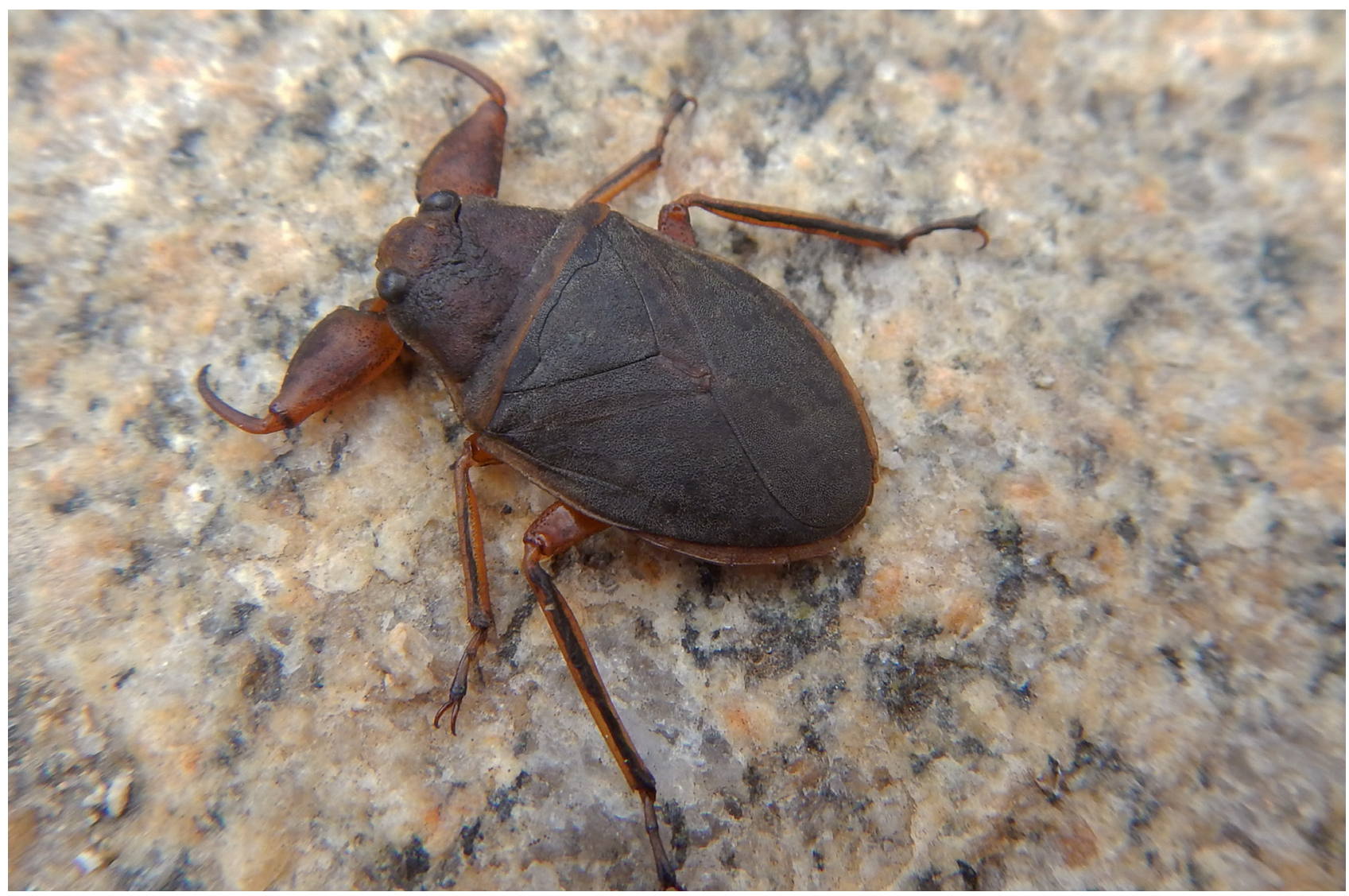

Figure 4. Staged specimen of Cataractocoris macrocephalus (Río Rana, Oaxaca). 


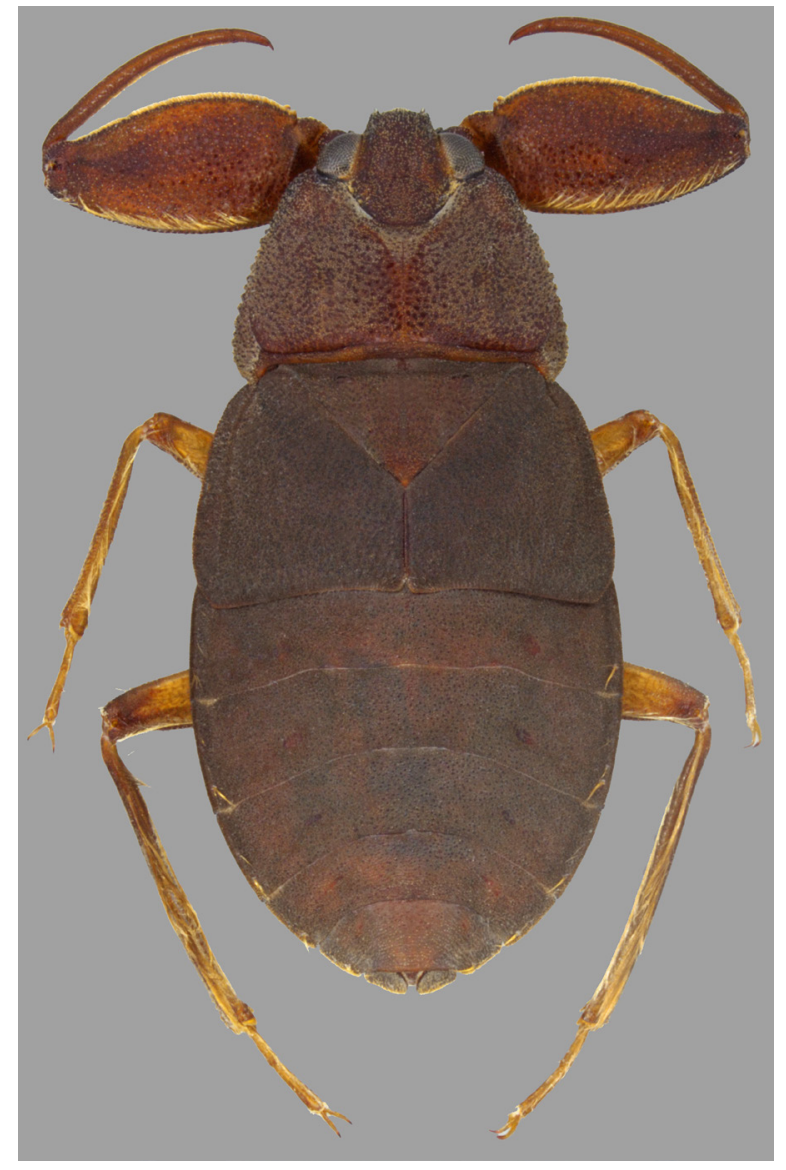

Figure 5. Brachypterous female of Cryphocricos hungerfordi (Altotonga, Veracruz).

it from the Old World and South American species. Later, the subgenus Interocoris was elevated to full generic status (Polhemus and Polhemus 2008b). A more detailed taxonomic study is needed to address the classification of this monotypic taxon and related taxa. The genus Ctenipocoris Montandon, also a member of Laccocorinae, is represented in the Neotropics by six species. Five of those are distributed in South America and only one species has been reported as far north as Costa Rica (Herrera 2013). This genus has at least one representative in Mexico; we have examined specimens collected in the southern states of Chiapas and Yucatán. Our understanding of the taxonomy of this genus is poor and the available literature is not sufficient to enable confident identification of the specimens from Mexico.

The subfamily Naucorinae, with 11 genera and 80 described species worldwide, is represented in the New World by two genera, one of which occurs in Mexico. Pelocoris Stål is most diverse in South America and has been revised for the United States and Canada (Polhemus and Sites 1995, Sites and Polhemus 1995, Sites 2015); however, the fauna of Mexico is uncertain. Currently, two species of Pelocoris have been recorded in Mexico, Pelocoris biimpressus Montandon (Fig. 8) and P. femoratus (Palisot de Beauvois), and we have seen at least one undescribed species in museums. Of these, Pelocoris biimpressus is the most common and is widespread. Pelocoris femoratus is common throughout the eastern United States and Canada

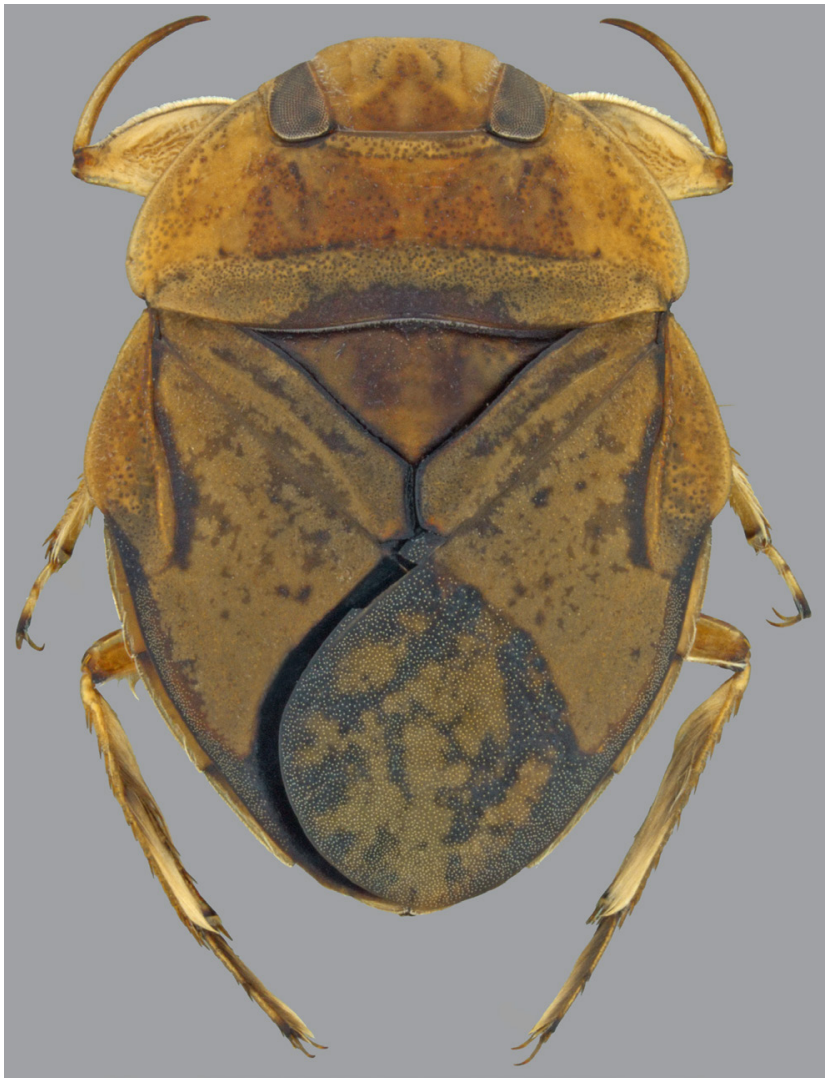

Figure 6. Male of Limnocoris signoreti (Putla de Guerrero, Oaxaca) (det. H.D.D. Rodrigues).

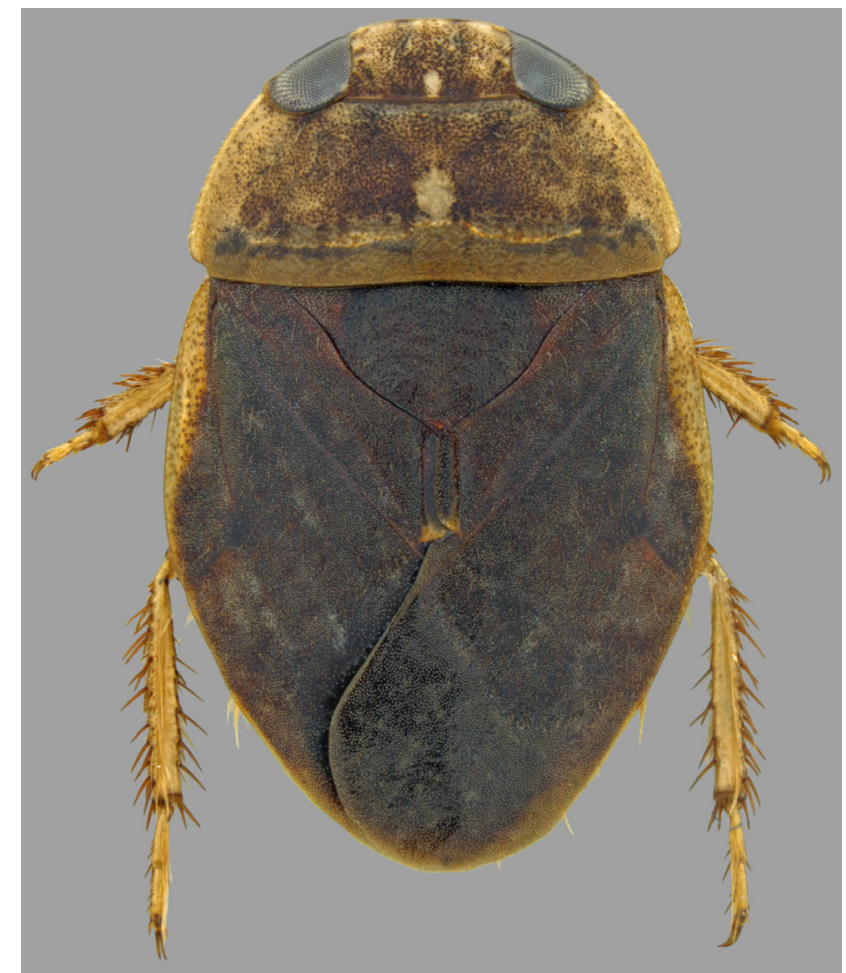

Figure 7. Male of Interocoris mexicanus (Motozintla, Chiapas). 


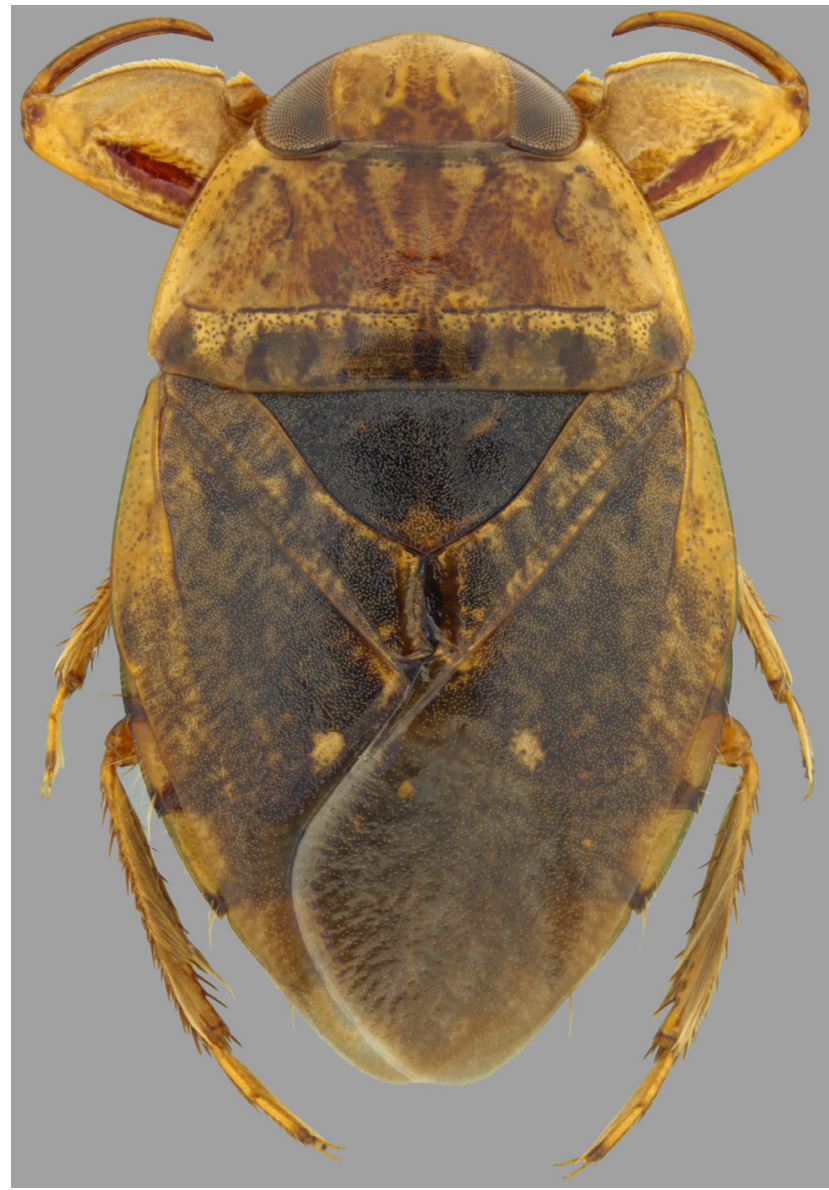

Figure 8. Female of Pelocoris biimpressus (Los Sabinos, Michoacán).

and numerous erroneous records are from as far south as Uruguay (Sites et al. 2018). Although P. femoratus has been reported from northeastern Mexico (Roback and Nieser 1974), Tamaulipas (Davis 1986), and Yucatán (Hungerford 1936), these records require confirmation because misidentifications in this genus are frequent. Nonetheless, a valid recent record of $P$. femoratus from Belize (Sites et al. 2018) suggests the species also occurs in eastern Mexican lowlands. A comprehensive taxonomic revision of the genus will help to clarify the status of the Mexican fauna of Pelocoris.

\section{SUBFAMILY CRYPHOCRICINAE GENUS Ambrysus Stål SUBGENUS Ambrysus Stål}

Species complex Ambrysus guttatipennis Stål

Ambrysus arizonus La Rivers, 1951

Distribution: Sonora

A. ayoyolin Reynoso and Sites, 2016

Distribution: Hidalgo

A. bispinus La Rivers, 1953

Distribution: Chiapas, Michoacán, Oaxaca Puebla, Veracruz.

A. bowlesi Reynoso and Sites, 2016

Distribution: Chihuahua, Durango, Jalisco, Sinaloa.

A. contrerasi Reynoso and Sites, 2016

Distribution: Estado de México, Guerrero, Jalisco,
Michoacán, Morelos.

A. drakei La Rivers, 1957

Distribution: Durango, Jalisco, San Luis Potosí, Zacatecas.

A. guttatipennis Stål, 1876

Distribution: Ciudad de México, Guanajuato, Hidalgo, Morelos, Oaxaca, Puebla, Querétaro, San Luis Potosí, Veracruz.

A. itsipatsari Reynoso and Sites, 2016

Distribution: Michoacán.

A. mexicanus Montandon, 1897

Distribution: Estado de México, Guerrero, Jalisco, Michoacán, Morelos, Oaxaca, Puebla.

A. mormon Montandon, 1909

Distribution: Chihuahua, Durango, Sonora.

A. noveloi Reynoso and Sites, 2016

Distribution: Jalisco.

A. veracruzanus Reynoso and Sites, 2016

Distribution: Veracruz.

\section{Species complex Ambrysus hybridus Montandon}

A. convexus Usinger, 1946

Distribution: Estado de México, Michoacán, Morelos.

A. fuscus Usinger, 1946

Distribution: Estado de México, Morelos.

A. hybridus Montandon, 1897

Distribution: Chihuahua, Durango, Estado de México,

Guanajuato, Hidalgo, Nuevo León, Oaxaca, Puebla, Querétaro, Sonora.

A. lariversi Reynoso and Sites, 2016

Distribution: Durango.

A. lattini La Rivers, 1976

Distribution: Chihuahua, Durango.

A. plautus Polhemus and Polhemus, 1982

Distribution: Chihuahua, Durango.

A. spiculus Polhemus and Polhemus, 1981

Distribution: Chihuahua, Durango, Sinaloa, Sonora, Zacatecas.

A. ultimus La Rivers, 1976

Distribution: Puebla.

\section{Species complex Ambrysus pudicus Stål Subcomplex subpilosus}

A. pudicus Stål, 1862

Distribution: Chiapas, Coahuila, Estado de México, Guanajuato, Guerrero, Hidalgo, Jalisco, Michoacán, Morelos, Nayarit, Nuevo León, Oaxaca, Puebla, Querétaro, San Luis Potosí, Sinaloa, Sonora, Tamaulipas, Veracruz.

\section{A. abortus La Rivers, 1953}

\section{Subcomplex pilosus}

Distribution: Estado de México, Guerrero, Jalisco, Michoacán, Morelos, Nayarit, Oaxaca, Puebla, Sinaloa.

A. angularis La Rivers, 1953

Distribution: Guerrero, Jalisco, Michoacán, Oaxaca.

A. chinanteco Reynoso and Sites, 2018 Distribution: Oaxaca.

A. hungerfordi Usinger, 1946

Distribution: Chihuahua, Durango, Guanajuato, Jalisco, Michoacán, Nayarit, Querétaro, San Luis Potosí, Sinaloa, Sonora. 
A. parviceps Montandon, 1897

Distribution: Chiapas, Colima, Estado de México, Guerrero, Jalisco, Michoacán, Morelos, Nayarit, Oaxaca, Puebla, San Luis Potosí.

A. spicatus La Rivers, 1953

Distribution: Chiapas, Oaxaca.

A. triunfo La Rivers, 1953

Distribution: Baja California Sur.

Species complex Ambrysus pulchellus Montandon

A. buenoi Usinger, 1946

Distribution: Chihuahua.

A. pulchellus Montandon, 1897

Distribution: Chiapas, Coahuila, Colima, Estado de México, Guerrero, Hidalgo, Jalisco, Michoacán, Morelos, Nayarit, Nuevo León, Oaxaca, Puebla, Querétaro, San Luis Potosí, Sinaloa, Sonora, Tamaulipas, Veracruz.

A. vanduzeei Usinger, 1946

Distribution: Baja California, Baja California Sur.

Species not in a defined complex

A. colimanus Polhemus and Polhemus, 1981 Distribution: Colima.

A. cosmius La Rivers, 1953

Distribution: Estado de México, Guerrero, Morelos, Oaxaca.

A. hydor La Rivers, 1953 Distribution: Estado de México, Guerrero, Jalisco, Michoacán, Morelos.

A. inflatus La Rivers, 1953 Distribution: Ciudad de México, Jalisco, Michoacán.

A. lunatus Usinger, 1946 Distribution: Puebla.

A. lundbladi Usinger, 1946 Distribution: Morelos.

A. magniceps La Rivers, 1953 Distribution: Estado de México.

A. melanopterus Stål, 1862 Distribution: Estado de México, Guerrero, Nayarit.

A. occidentalis La Rivers, 1951

Distribution: Baja California, Sinaloa, Sonora.

A. portheo La Rivers, 1953 Distribution: Coahuila.

A. puncticollis Stål, 1876 Distribution: Sinaloa, Sonora.

A. quadracies La Rivers, 1976 Distribution: Veracruz.

A. rotundus La Rivers, 1962 Distribution: San Luis Potosí.

A. scalenus La Rivers, 1953 Distribution: Michoacán.

A. signoreti Stål, 1862 Distribution: México (not a specific locality).

A. sonorensis Usinge,r 1946

Distribution: Sonora.

\section{SUBGENUS Syncollus La Rivers}

A. baeus Polhemus and Polhemus ,1981 Distribution: Chiapas, Colima, Jalisco, Michoacán, Nayarit, Oaxaca, San Luis Potosí, Veracruz.
A. chiapanecus Reynoso, Sites, and Novelo, 2016 Distribution: Chiapas.

A. circumcinctus Montandon, 1910 Distribution: Chiapas, Chihuahua, Coahuila, Durango, Estado de México, Guerrero, Hidalgo Jalisco, Michoacán, Morelos, Nayarit, Nuevo León, Oaxaca, Puebla, San Luis Potosí, Sinaloa, Sonora, Tabasco, Tamaulipas, Veracruz, Zacatecas.

A. pygmaeus La Rivers, 1953 Distribution: Durango, Estado de México, Morelos, Oaxaca.

A. totonacus Reynoso, Sites, and Novelo, 2016 Distribution: Hidalgo, Puebla, Veracruz.

A. xico Reynoso, Sites, and Novelo, 2016 Distribution: Querétaro, Veracruz.

GENUS Cataractocoris Usinger

Cataractocoris macrocephalus (Montandon), 1897 Distribution: Chiapas, Estado de México, Jalisco, Morelos, Veracruz.

C. marginiventris Usinger, 1941

Distribution: Chiapas, Estado de México, Guerrero, Jalisco, Morelos, Michoacán, Oaxaca, Puebla, Veracruz.

C. shepardi Sites, Reynoso, and Novelo, 2013 Distribution: Chiapas, Jalisco, Nayarit, Oaxaca, Veracruz.

GENUS Cryphocricos Signoret

Cryphocricos hungerfordi Usinger, 1947 Distribution: Coahuila, Veracruz.

C. mexicanus Usinger, 1947

Distribution: Estado de México.

\section{SUBFAMILY LACCOCORINAE GENUS Interocoris La Rivers}

Interocoris mexicanus (Usinger), 1935

Distribution: Chiapas, Estado de México, Guerrero, Jalisco, Nayarit, Oaxaca, Sonora.

\section{SUBFAMILY LIMNOCORINAE GENUS Limnocoris Stål}

Limnocoris borellii Montandon, 1897 Distribution: México (not a specific locality).

L. brailovsky La Rivers, 1976

Distribution: Jalisco.

L. hintoni La Rivers, 1970 Distribution: Estado de Mexico, Jalisco, Puebla.

L. laucki La Rivers, 1970 Distribution: Nayarit.

L. lutzi La Rivers, 1957

Distribution: Coahuila, Oaxaca, San Luis Potosí, Veracruz.

L. profundus (Say), 1832 Distribution: México (not a specific locality).

L. pygmaeus La Rivers, 1956 Distribution: Guerrero, Jalisco, Sinaloa, Sonora.

L. signoreti Montandon, 1897 Distribution: México (not a specific locality).

L. solenoides La Rivers, 1970 Distribution: Oaxaca. 
L. stangei La Rivers, 1976 Distribution: Nayarit.

\section{SUBFAMILY NAUCORINAE GENUS Pelocoris Stål}

Pelocoris biimpressus Montandon, 1898 Distribution: Chiapas, Jalisco, Puebla, San Luis Potosí, Sinaloa, Sonora, Tamaulipas, Veracruz.

P. femoratus (Palisot de Beauvois), 1805 Distribution: Tamaulipas, Yucatán.

\section{Key to the subfamilies and genera of Naucoridae from Mexico}

(modified from Reynoso-Velasco et al. 2016)

1 Front of head folded posteroventrally .. (Laccocorinae)

1' Front of head not folded posteroventrally .................. 3

2 Protarsus of female one-segmented. Posterior part of mesosternum in both sexes bulging along midline; generally with a round light spot posteromedially on pronotum ............................... Interocoris La Rivers

2' Protarsus of female two-segmented. Posterior part of mesosternum in both sexes flat; without light spot on pronotum ......................... Ctenipocoris Montandon

3 Anterior margin of pronotum straight or slightly concave behind interocular space ..................................... 4

3 ' Anterior margin of pronotum deeply emarginate behind interocular space .. (Cryphocricinae)

4 Inner margin of eyes diverging anteriorly; meso- and metasterna with prominent longitudinal carinae ........ (Limnocorinae) ............................ Limnocoris Stål

4' Inner margins of eyes converging anteriorly; meso- and metasterna without prominent longitudinal carinae .... (Naucorinae) ....................................... Pelocoris Stål

5 Propleura extending mesad to cover posterior portion of prosternum (prosternellum) and contiguous or nearly so at midline; abdominal sternum densely pubescent; fore wing macropterous forms .............................. 6

5' Prosternum exposed, without mesal extensions of propleura; abdominal sternum glabrous; fore wing brachypterous and macropterous forms

Cryphocricos Signoret

6 Body surface covered with scattered granules; eyes distinctly elevated and subglobose; abdominal sternum with wide, lateral glabrous band; meso- and metapretarsal claws large and strongly curved over entire length nearly to semicircle

Cataractocoris Usinger

6' Body surface without granules; eyes scarcely elevated above surface of head; abdominal sternum almost entirely pubescent, lateral glabrous band narrow; meso- and metapretarsal claws small with curvature mostly in distal half and never to semicircle

Ambrysus Stål

Our objective for the immediate future is to complete the taxonomic revision of the genus Ambrysus in North America and present a phylogenetic analysis of species in the subfamily Cryphocricinae based on nuclear and mitochondrial genes. Thereafter, we plan on taxonomic revisions of the genera Ctenipocoris, Cryphocricos, and Pelocoris.
We encourage colleagues worldwide to contact us if they are interested in establishing collaborations to study aquatic and semi-aquatic Heteroptera.

\section{LITERATURE CITED}

Champion, G. C. 1901. Fam. Naucoridae. (pp. 354-361). In: Godman F.D. and O. Salvino (Eds.). Biologia CentraliAmericana Vol. II Rhynchota. Hemiptera-Heteroptera. R.H. Porter, London, [1897-1901].

Davis, J.R. 1986. New distributional records of Naucoridae (Hemiptera) from the United States and Mexico with morphological and taxonomic notes. The Southwestern Naturalist, 31(4): 535-539.

Davis, J.R. 1996. The creeping water bugs (Hemiptera: Naucoridae) of Texas. The Southwestern Naturalist, 41(1): 1-26.

Herrera, F. 2013. Estado del conocimiento y catálogo de la familia Naucoridae (Insecta: Heteroptera) en Centroamérica. Dugesiana, 20(2): 221-232.

Hungerford, H.B. 1936. Aquatic and semiaquatic Hemiptera collected in Yucatan and Campeche. The cenotes of Yucatan: A zoological and hydrographic survey. Carnegie Institute of Washington Publications, 157: 145-150.

La Rivers, I. 1951. A revision of the genus Ambrysus in the United States (Hemiptera: Naucoridae). University of California Publications in Entomology, 8(7): 277-338.

La Rivers, I. 1953. The Ambrysus of Mexico (Hemiptera, Naucoridae). The University of Kansas Sciences Bulletin, 35(10): 1279-1349.

La Rivers, I. 1957. A new Ambrysus from Mexico (Hemiptera, Naucoridae). Entomological News, 68(9): 232-237.

La Rivers, I. 1967. Descriptions of new bugs. Biological Society of Nevada Occasional Papers, (14): 1-8.

La Rivers, I. 1971. Studies of Naucoridae (Hemiptera). Biological Society of Nevada Memoirs, 2: 1-120.

La Rivers, I. 1974. Catalogue of the taxa described in the family Naucoridae (Hemiptera). Supplement No. 1: corrections, emendations and additions, with descriptions of new species. Occasional papers of the Biological Society of Nevada, (38): 1-17.

La Rivers, I. 1976. Supplement No. 2 to the catalogue of taxa described in the family Naucoridae (Hemiptera) with descriptions of new species. Biological Society of Nevada Occasional Papers, (41): 1-17.

Mayr, E. 1982. Of what use are subspecies? The Auk, 99(3): 593-595.

Morrone, J.J. (2005) Towards a synthesis of Mexican biogeography. Revista Mexicana de Biodoversidad, 76(2): 207-252.

Polhemus, J.T. and D.A. Polhemus. 1981. Three new species of Ambrysus from Mexico (Hemiptera: Naucoridae). The Pan-Pacific Entomologist, 57(3): 397-401.

Polhemus, J.T. and D.A. Polhemus. 1983. Notes on Neotropical Naucoridae II. A new species of Ambrysus and review of the genus Potamocoris (Hemiptera). The Pan-Pacific Entomologist, 58(4): 326-329.

Polhemus, J.T. and D.A. Polhemus. 2008a. Global diversity of true bugs (Heteroptera: Insecta) in fresh water. Hydrobiologia, 595(1): 379-391. 
Polhemus, J.T. and D.A. Polhemus. 2008b. Intraspecific morphological polymorphism in Naucoridae (Hemiptera: Heteroptera) with notes on nomenclature and synonymy. Acta Entomologica Musei Nationalis Pragae, 48(2): 289-298.

Polhemus, J. T. and R.W. Sites. 1995. The identity of Pelocoris biimpressus Montandon and synonym of Pelocoris species in the southwestern United States (Heteroptera: Naucoridae). Proceedings of the Entomological Society of Washington, 97(3): 654-658.

Reynoso-Velasco, D. and R.W. Sites. 2016a. Revision of the Ambrysus guttatipennis Stål species complex (Heteroptera: Naucoridae: Cryphocricinae) with the description of six new species from Mexico. Zootaxa, 4154(3): 201-250.

Reynoso-Velasco, D. and R.W. Sites. 2016b. Revision of the Ambrysus hybridus Montandon species complex (Heteroptera: Naucoridae: Cryphocricinae) with the description of a new species from Mexico. Zootaxa, 4169(1): 87-114.

Reynoso-Velasco, D. and R.W. Sites. 2018a. Revision of the Ambrysus pulchellus Montandon species complex (Heteroptera: Nepomorpha: Naucoridae). Zootaxa, 4442(3): 351-377.

Reynoso-Velasco, D. and R.W. Sites. 2018b. Revision of the Ambrysus pudicus Stål species complex (Heteroptera: Nepomorpha: Naucoridae) with the description of a new species from southern Mexico. Zootaxa (in press).

Reynoso-Velasco, D., R.W. Sites and R. Novelo-Gutiérrez. 2016. The Ambrysus Stål (Heteroptera: Naucoridae: Cryphocricinae) of Mexico: Revision of the subgenus Syncollus La Rivers. Zootaxa, 4126(1): 44-76.

Roback, S.S. and N. Nieser. 1974. Aquatic Hemiptera (Heteroptera) from the Llanos of Colombia. Proceedings of the Academy of Natural Sciences of Philadelphia, 126(4): 29-49.

Schuh, R.T. and J.A. Slater. 1995. True bugs of the world (Hemiptera: Heteroptera): classification and natural history. Cornel University Press, Ithaca.

Sites, R.W. 2015. Pelocoris balius La Rivers (Hemiptera: Heteroptera: Naucoridae) in Florida: new status of an enigmatic saucer bug. Zootaxa, 3915(3): 433-438.

Recibido: 2 de julio de 2018

Aceptado: 16 de agosto de 2018

Primero en línea: 20 de septiembre 2018

Online First Publication: 20th september 2018
Sites, R.W. and D. Reynoso-Velasco. 2015. Review of the Ambrysus stali La Rivers species complex (Heteroptera: Nepomorpha: Naucoridae) with the description of a new species from Mesoamerica. Zootaxa, 4018(2): 279-291.

Sites, R.W. and J.T. Polhemus. 1995. The Pelocoris (Hemiptera: Naucoridae) fauna of Texas. The Southwestern Naturalist, 40(3): 249-254.

Sites, R.W. and W.D. Shepard. 2015. Neotropical genera of Naucoridae (Hemiptera: Heteroptera: Nepomorpha): New species of Ambrysus and Procryphocricos from Belize and Peru. Annals of the Entomological Society of America, 108(4): 613-620.

Sites, R.W., D. Reynoso-Velasco and R. NoveloGutiérrez. 2013. Revision of the Mesoamerican genus Cataractocoris Usinger (Hemiptera: Heteroptera: Nepomorpha: Naucoridae). Zootaxa, 3682(3): 475-484.

Sites, R.W., R.H. Carrie and W.D. Shepard. 2018. The Naucoridae (Heteroptera: Nepomorpha) of Belize. Aquatic Insects, DOI: 10.1080/01650424.2018.1450988

Štys, P. and A. Jansson. 1988. Check-list of recent family-group and genus-group names of Nepomorpha (Heteroptera) of the world. Acta Entomologica Fennica, 50: $1-44$.

Usinger, R.L. 1935. A second American species of the naucorid subfamily Laccocorinae (Hemiptera). Revista de Entomologia, 5(2): 133-136.

Usinger, R.L. 1946. Notes and descriptions of Ambrysus Stål with an account of the life history of Ambrysus mormon Montd. (Hemiptera, Naucoridae). The University of Kansas Sciences Bulletin, 31(10): 185-210.

Usinger, R.L. 1947. Classification of the Cryphocricinae (Hemiptera: Naucoridae). Annals of the Entomological Society of America, 40(2): 329-343.

Usinger, R.L. 1972. Robert Leslie Usinger: Autobiography of an entomologist. Memoires of the Pacific Coast Entomological Society, 4: 1-330.

Wilson, E.O. and W.L. Brown Jr. (1953) The subspecies concept and its taxonomic application. Systematic Zoology, 2(3): 97-111. 